\title{
A népegészségügyi adatgyưjtések etikai vonatkozásai Az Egészségügyi Világszervezet újonnan közzétett irányelveinek ismertetése
}

\author{
Review of the WHO guidelines on ethical issues in public health surveillance
}

Szerzők: Vitrai József $\bowtie$

Emberi Erőforrások Minisztériuma

Beküldve: 2017.09.14.

doi: 10.24365/ef.v58i3.174

Kulcsszavak: adatgyújtés; etika; irányelv

Keywords: surveillance; ethics; guideline

Az Egészségügyi Világszervezet (WHO) népegészségügyi adatgyűjtésekhezi közreadott etikai irányelvei ${ }^{1}$ az első olyan nemzetközi koncepció, amely a maga nemében igen fontos hiányosságot pótol. Az irányelvfejlesztési projekt célja az volt, hogy segítse a politikai döntéshozókat és irányítsa a szakembereket a népegészségügyi adatgyűjtések által felvetett etikai kérdésekben. Ez a dokumentum 10 olyan etikai irányelvet határoz meg, amelyek segítséget nyújthatnak mindazoknak, akik népegészségügyi adatgyüjtésekben vesznek részt, beleértve a kormányzati hivatalok tisztviselőit, az egészségügyi dolgozókat, a nem kormányzati szervezeteket és a magánszektort.

\section{AZ ADATGYŰJTÉSEK ETIKAI KOCKÁZATA}

Az etikusan végrehajtott népegészségügyi adatgyűjtések nélkülözhetetlenek az emberek jóllétét elősegítő programok megvalósításához. Hozzájárulhat az egyenlőtlenségek csökkentéséhez: a tisztességtelen, igazságtalan és megelőzhető szenvedések nem csökkenthetők, ha először nem válnak láthatóvá. De az adatgyűjtések kockázatot jelenthetnek a résztvevők számára, és ez néha etikai dilemmákat okoz. A magánéletre, az autonómiára, a méltányosságra és a közösség jóllétére vonatkozó problémákat kezelni, és megtalálni a megfelelő egyensúlyt a gyakorlatban nagy kihívást jelenthet. Ehhez kíván a WHO az irányelvekkel segítséget nyújtani.

A betegségekre vonatkozó adatgyújtés a XIX. század végétől alapvető népegészségügyi tevékenység. $A$ népegészségügyi adatgyűjtés teszi lehetővé a járványok kitörésének megakadályozását és a szükséges válaszlépések megtételét, de jelentősége a fertőző betegségeken messze túlterjed. Jól látható ez az 1 . táblázat alapján, amely a megfigyelt terület, a megfigyelés céljai, az adatgyújtés és az elemzés módszerei, valamint az eredmények hasznosítása szerint jellemzi ezt a tevékenységet.

A népegészségügyi adatgyűjtések gyakran úgy történnek, hogy a lakosság nincs tudatában az adatgyűjtés következtében felmerülő megbélyegzés, megkülönböztetés vagy az egyenlőtlenségek elmélyítésének kockázatával. Maga a tevékenység

'A dokumentumban szereplő public health surveillance kifejezést népegészségügyi adatgyűjtésnek fordítottuk. 
ugyanakkor elkerülhetetlenül együtt jár értékek és ítéletek konfliktusaival azzal kapcsolatban, hogy hogyan lehet összeegyeztetni az össztársadalmi célokat az egyének és csoportok érdekeivel. Bár jól ismertek a tudományos kutatásokra kidolgozott etikai irányelvek - beleértve a járványtani, epidemiológiai vizsgálatokra vonatkozóakat is -, eddig még nem került sor azoknak az elméleti kereteknek a kimunkálására, amelyek a népegészségügyi adatgyűjtések etikus megvalósítását támogatják a fertőző betegségektől a nem fertőző krónikus betegségeken keresztül a környezeti és foglalkozási kockázatokig terjedő területeken.

1. táblázat: A népegészségügyi adatgyüjtések dimenziói

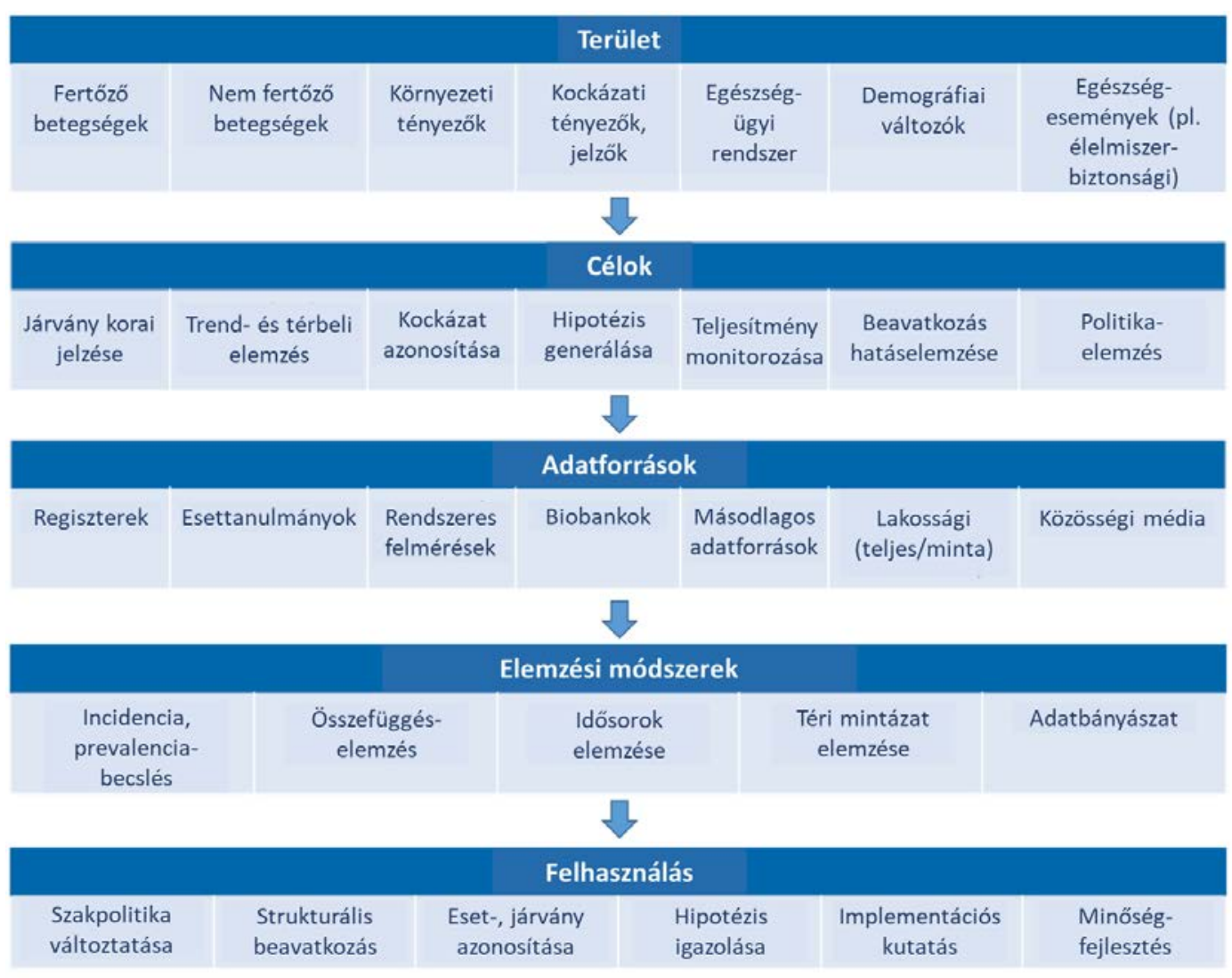

A WHO szakdokumentuma a II. fejezetben áttekinti a népegészségügyi adatgyújtések különböző értelmezését, és leszögezi: „Ez az irányelv az adatgyűjtést tágan értelmezi” (14. o.). Alátámasztásul hivatkozik a következő meghatározásra: az adatgyújtés olyan „egészséggel kapcsolatos folyamatos, rendszeres gyűjtés, elemzés és értékelés, amely a népegészségügyi tevékenységek tervezését, megvalósítását és értékelését szolgálja." ${ }^{2}$ Az írás röviden bemutatja, hogyan alakult a népegészségügyi adatgyújtéssel kapcsolatos, a tagállamok által 2005-ben elfogadott nemzetközi szabályozás (International Health Regulations).

A dokumentum III. fejezete érintve az eddigi releváns etikai irányelveket összefoglalja a népegész- ségügy elmúlt két évtizedben megfogalmazott etikai alapelveit: a közös érdeket, a méltányosságot, a szolidaritást, a viszonosságot és a lakosság jóllétét. A WHO irányelvét kidolgozó szakértők a közös érdek, a méltányosság, az egyének tisztelete, illetve a jó kormányzás etikai elvét tartották alapvetőnek a népegészségügyi adatgyűjtés etikai irányelvének meghatározásához.

A WHO dokumentum IV. fejezete sorolja fel és fejti ki az alábbi etikai irányelveket, amelyek egyrészt lefedik a megvalósítók felelősségét, másrészt a résztvevők védelmének kötelezettségét, harmadrészt az eredmények kommunikálására és az adatok megosztására vonatkozó megfontolandókat. 


\section{IRÁNYELVEK}

1. Minden országnak kötelezettsége, hogy megfelelő, fenntartható népegészségügyi adatgyűjtést alakítson ki. Az adatgyújtési rendszernek rendelkeznie kell világosan megfogalmazott célokkal és az adatgyújtésre, az elemzésre, valamint a releváns népegészségügyi prioritásokhoz kapcsolt felhasználásra vonatkozó tervvel.

2. Minden országnak kötelezettsége, hogy olyan megfelelö, hatékony eljárást dolgozzon ki, amely az adatgyűjtések etikus megvalósítását biztosítja.

3. Adatok csak jogszabályban rögzített népegészségügyi célból gyưjthetők.

4. Minden országnak kötelezettsége, hogy a népegészségügyi célok eléréséhez gyűjtött adatok megfelelő minőségét biztosítsa, beleértve az időszerűséget, a megbízhatóságot és az érvényességet.

5. A népegészségügyi adatgyűjtés tervezését közzétett kormányzati prioritásokra kell alapozni.

6. A globális közösségnek kötelessége támogatni olyan országok adatgyújtését, amelyek nem rendelkeznek ahhoz elégséges erőforrással.
7. A népegészségügyi adatgyűjtések tervezésekor, megvalósításakor és eredményeinek felhasználásakor figyelembe kell venni a különböző társadalmi csoportok értékeit, aggályait.

8. A népegészségügyi adatgyűjtések megvalósítóinak az esetleges károk (2. táblázat) minimalizálása érdekében előzetesen kell azonosítaniuk, értékelniük a kockázatokat, és azokat nyilvánosságra kell hozniuk. Gondoskodni kell a károk folyamatos monitorozásáról, és amennyiben valamilyen károkozásra fény derül, megfelelő beavatkozást kell alkalmazni az enyhítésére.

9. Ha az adatgyűjtésbe olyan egyéneket vagy társadalmi csoportokat vonnak be, akik betegségek, megkülönböztetés és igazságtalanság által különösen veszélyeztetettek, kritikus és gondos elemzéssel arra kell törekedni, hogy ne érje őket szükségtelen terhelés.

10.A népegészségügyi adatgyújtés keretében a személyek azonosítására alkalmas adatok biztonságát a kormányzat és a közremúködő szervezetek kötelesek szavatolni.

A hazai népegészségügyi szakemberek számára bizonyosan hasznosak lesznek a bemutatott irányelvek a magyarországi népegészségügyi adatgyűjtési rendszer jövőbeli tervezésekor és múködtetésekor.

2. táblázat: Népegészségügyi adatgyüjtések adatainak feltárásából eredő esetleges károk

\begin{tabular}{|c|l|}
\hline Ártalom & \multicolumn{1}{|c|}{ Következmény } \\
\hline Testi & $\begin{array}{l}\text { Közterületi támadás, partner-, családi erőszak, késedelmes vagy } \\
\text { elmaradt kezelés } \\
\text { Letartoztatás, vádelemelés, halálbüntetés, kiutasitás }\end{array}$ \\
\begin{tabular}{|l} 
Jogi \\
Szociális
\end{tabular} & $\begin{array}{l}\text { Diszkrimináció, kollektiv diszkrimináció, elszigeteltség, ellátáshoz } \\
\text { való hozzáférés akadályoztatása, kiközösítés } \\
\text { Munkahely, jövedelem elvesztése; ellátásból kizárás; biztositás elvesztése; } \\
\text { biztositási dij, ellátási költségek növekedése; karrierlehetöségek, } \\
\text { létfenntartási eróforrások beszúkülése; kényszerköltözés }\end{array}$ \\
\hline Pszichikai, érzelmi & Zavar, trauma, stigmatizáció \\
\hline
\end{tabular}

HIVATKOZÁSOK

1 WHO guidelines on ethical issues in public health surveillance, WHO 2017; http://www.who.int/ethics/publications/public-health-surveillance/en/ (Elérve: 2017. 08. 28.)

2 WHO health topics | Public health surveillance. Geneva: World Health Organization, 2014; http://www.who.int/topics/public health surveillance/en/; (Elérve: 2017. 08. 29.) 